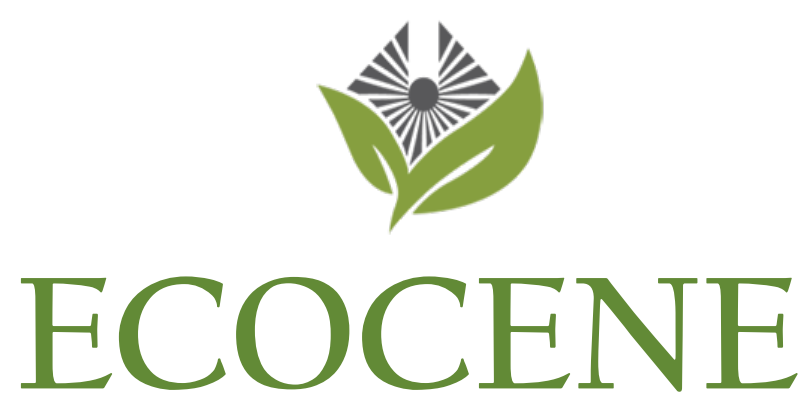

CAPPADOCIA JOURNAL OF ENVIRONMENTAL HUMANITIES

Volume 1/ Issue 1/June 2020

Environmental Humanists Respond to the World Scientists' Warning to Humanity

\title{
Speaking for the Earth and Humans In the "Age of Consequences"
}

\author{
Noel Castree \\ University of Manchester, UK \\ University of Wollongong, Australia \\ noel.castree@manchester.ac.uk \\ ORCID: 0000-0002-0282-531
}

Castree, Noel. 2020. "Speaking for the Earth and Humans in the 'Age of Consequences'." Ecocene: Cappadocia Journal of Environmental Humanities 1, no. 1 (June): 32-43.

https://doi.org/10.46863/ecocene.2020.4.

Research Article/ Received: 07.05.2020 /Accepted: 05.06.2020

This work is licensed under a Creative Commons Attribution 4.0 International License. (c) (i) 


\title{
Speaking for the Earth and Humans in the "Age of Consequences" by Noel Castree
}

\begin{abstract}
The environmental humanities are suffused with a sense of urgency. As geoscientists sound the alarm about human treatment of the Earth, likewise environmental humanists seek to trigger the "conversation of humankind" that seems scarcely to be happening outside universities. This essay ponders the future of the environmental humanities, and specifically their relationship to the geosciences whose messages animate much current humanistic inquiry. It cautions against a too-hasty acceptance of the notion of a "global environmental crisis." It argues for forms of interdisciplinary work that give humanists parity-of-esteem with geoscientists. And it suggests that a modified paradigm of global environmental assessment might be a viable vehicle for greater humanistic influence in the global public sphere. Throughout, humanists must somehow balance trust in geoscience with a critical stance towards its core messages about a changing Earth system. This stance is anchored on the ground of democracy, the necessary political basis for any legitimate decisions about humanity's future on Earth. Steering the environmental humanities will be a major challenge given the need for humanists to retain academic freedom yet cooperate in order to exert influence outside the academic domain.
\end{abstract}

Keywords: geoscience, environmental crisis, expertise, global environmental assessment

About the Author

Noel Castree is a Professor of Geography at Manchester University, England, and an Honorary Professorial Fellow in the School of Geography at the University of Wollongong, Australia. After his doctoral studies at the University of British Columbia, his early research examined capitalism-environment relationships using Marxist theory. His broader interest in how 'nature' is framed in both academia and the wider society later led to several books, including Making Sense of Nature (Routledge, 2014). In recent years, he has focused on who speaks for the Earth, tracking the changing registers and impacts of "expertise." He is currently writing a book entitled Future Earth (Routledge, 2022). It focuses on the content and politics of authoritative discourse about people and the planet. 


\title{
Speaking for the Earth and Humans in "the Age of Consequences"
}

\author{
Noel Castree
}

The world is neck-deep in the COVID-19 crisis at the time of writing. Having so swiftly exposed our shocking vulnerability (even in the richest countries), the pandemic has made philosophers of us all. People have been forced to ask big questions about things they take-for-granted. The unthinkable has not simply been thought: governments have also acted accordingly. In the blogosphere, news articles and numerous editorials, the words of Winston Churchill have been a touchstone here in the UK, where I am based. "The era of procrastination, of half-measures, of soothing and baffling expedients," he memorably said in 1936, "is coming to its close. In its place we are entering a period of consequences" (2003, 142). Three years after he uttered these prescient words, the world was at war. That long conflagration was a break-point in human (and environmental) history, more so even than its predecessor of 1914-18. Will the "war" on the coronavirus produce a root-and-branch review of how we currently live, thereby preventing future pandemics before they wreak havoc? Or will it give way to regulatory tinkering and a modified version of business-as-usual?

As we look ahead, the mind-boggling changes to human behavior caused by COVID-19-mandated by new government laws, directives and policies-not only raise important questions about anti-viral resilience. They also raise parallel questions about how humans will address a very familiar, but slow-burning, crisis: that of our collective treatment of the biosphere, hydrosphere, atmosphere, cryosphere and pedosphere. The escalating scale, scope and magnitude of the human impact on Earth-what some geoscientists call The Great Acceleration (which began roughly 9 years after Churchill's speech in the House of Commons) - has been widely studied and reported. Geoscientists have been sounding the alarm for years, with some (like James Hansen) becoming in/famous in the process. 
Such has been the level of geoscientific concern about human mistreatment of the planet that more and more collective warnings have been issued. The two declarations inspiring this special issue are notable recent examples. Increasingly, the signatories of these clarion calls - numbering dozens, hundreds and even thousands of expertsinclude specialists hailing from social science and the humanities. The reason is obvious: these experts in the "people disciplines" seek to understand the so-called "human dimensions" of the multifaceted crisis, from causes through impacts to various possible responses. Even so, in the minds of most citizens, most governments and many a business, the "problem" of global environmental change remains framed by geoscientific reports about physical phenomena like Australian wildfires, coral bleaching, GHG emission levels, temperature goals and species extinctions. These reports remind us of the "sustainability gap" that's widening month by month. Closing it will be a formidable challenge. And we will need much more than techno-scientific know-how in order to avoid a "bad Anthropocene" (Nightingale et al. 2020).

In this short essay, I use the COVID-19 pandemic to think constructively but critically about how we might respond to the global environmental crisis. The we in question are people like me (forgive the conceit): researchers and teachers in the social sciences and humanities who examine human interactions with the biophysical world. Where geoscientists speak with authority-and increasing concern - about the state of that world, I ask what sort of stance we should adopt towards them and the realities they speak of in their papers, reports and declarations. I make a set of wider points with specific reference to the "environmental humanities," as befits the focus of this new journal. Rather as geoscientists have found ways to coordinate their research (and teaching) into what they these days call the Earth System, so many environmentallyminded humanists have begun to knit their inquiries together into something larger and, potentially, more prominent. The launch of Ecocene, following on the heels of Environmental Humanities (published by Duke University Press) and Resilience (Nebraska University Press), is testament to that - so too are a set of global observatories, agendasetting texts (e.g. Oppermann and Iovino 2017a), new research centers (e.g. at the Free University, Amsterdam) and a book series (notably a Routledge one, edited by Joni Adamson, Scott Slovic and Masumi Yuki). The environmental humanities are on the rise, and have been for some years now. But what pathways should they now follow and to which destinations? 


\section{Crises Fast and Slow}

Having already mentioned two coincident crises, I begin by exploring the (apparent) nature of both. This will help us understand how environmental social scientists and humanists might best respond to them.

In very many ways the COVID-19 crisis (I am writing in May 2020) is both unique and unprecedented. Its origins seemingly lay in a wet market in Wuhan (China), one whose decidedly "unnatural ecology" allowed interspecies interactions not found in the wild. Within 4 months the virus had spread to all points of the compass, travelling by land, air and sea along a set of long distance transportation arteries. It rapidly posed a potential threat to the totality of humanity, absent suitable methods of containment, prevention and patient care. The virus forced governments to act quickly to protect their citizens, especially in hard-hit countries such as Spain. The political rule book was thrown-out of the proverbial window. In the space of a few weeks, citizens worldwide-from Italy and India to Canada and Colombia-consented (or were forced to accept) restrictions on movement that would normally be deemed totally unacceptable. These were justified in the name of public health. Likewise, many governments enacted jaw-dropping measures to protect businesses, workers and government services, measures rarely seen even in war-time conditions. Suddenly, things usually depicted in Hollywood science-fiction films were part of our global actualité. People old and young have rarely experienced anything like it (and hopefully never will again). The impacts of the coronavirus crisis will be long-lasting and exceedingly ramified. For instance, there is much talk of not only recession but an economic depression.

Compare this with the crisis pronounced, ever more volubly, by geoscientists of various stripes. It's said to be a crisis of the entire Earth System, as humans push it out of its Holocene envelope. "Planetary boundaries" are being transgressed and we risk crossing various tipping points (Steffen et al. 2015; Lenton et al. 2019). When publishing the underpinning research, geoscientists employ measured language. But they are increasingly outspoken when identifying the possible consequences of not taking the research seriously. For instance, climatologist Michael Mann routinely writes newspaper columns and speaks in public about the large risks of missing the Paris Agreement targets. His injunction to other scientists is this: "If you see something, say something" (Mann 2014). This advice reflects the heavy burden people like Mann and Hansen shoulder: adapting Marx and Engels' famous words, "global environmental change cannot speak for itself, it must be spoken for." Expensive remote sensing systems, sophisticated computer models and highly trained personnel are needed to voice the planetary crisis in a credible way. In 2019, the term "climate emergency" 
became somewhat normalized-overdue pay-off for years of reporting by the IPCC and others. Yet, for most people, this crisis is nothing like as graphic and immediate as the COVID-19 pandemic is, even though it's clear that the two are causally linked.

Indeed, many people do not even recognize global environmental change as a crisis-including, it seems, many political leaders. Despite the best efforts of some, years of foot-dragging in the United Nations, and at the national level, suggest that governments worldwide continue to prioritize many other things. Their rhetoric is belied by lack of action. Unlike the current pandemic, the global environmental crisis is chronic, long-term and diffuse by human standards (albeit a blink of the eye in geological terms). The COVID-19 calamity seems to show us what it takes for societies worldwide to recognize the sort of "problem" that global environmental change represents. It's a problem so big and manifold that radical, far-reaching, indeed gamechanging actions are required. But unless the planetary crisis hits us square in the face, those actions may not eventuate at all (or at least not in a timely fashion). The scene is set for a global tragedy, as many have been saying for years.

\section{What to Do When the Alarm Bell Falls on Deaf Ears?}

The response to the coronavirus crisis is apparently a case of what Roger Pielke (2007), in his influential book about science and policy, called "tornado politics." When people know a tornado is likely to hit town, they act collectively and without hesitation to protect life and property. In these situations, politicians can occupy the high ground and act in the public interest (though, as America's Hurricane Katrina showed, are not always adept). Many people, such as the now iconic teenager Greta Thunberg, regard global environmental change as a similar case-albeit a latent one. What bothers environmental activists like her, and many geoscientists such as James Hansen, is the persistent failure to see the tornado for what it is. It's too often mistaken for a gale: an unwelcome but tolerable event. This misrecognition is much harder to rectify in a "post-truth" environment where fake news and "alternative facts" circulate widely, and where-in countries experiencing an ascendant populism-opinion and emotion substitute for reasoned and well-evidenced argument. How can all this be fixed?

There are no silver bullets, of course. However, it's clear that many environmental humanists are positioning themselves as amplifiers of the stark geoscience messages contained in documents like the "World Scientists' Warning of a Climate Emergency" published in the journal BioScience (Ripple et al. 2020). In a range of ways, they are seeking to defamiliarize and criticize business-as-usual in the realms of ethics, economics, policy and so on-often drawing on a wide range of religious and non- 
Western perspectives. This oppositional stance is, in fact, definitional of the environmental humanities for some who speak in their name. For instance, in their recent introduction to the field, Robert Emmett and David Nye (2017) note that "the... agenda of the environmental humanities emerged in response to a multi-pronged crisis of ecology, economy, politics and epistemology" (8). In their programmatic introduction to an edited collection showcasing environmental humanities research, Serpil Oppermann and Serenella Iovino (2017b) go further. Citing ecocriticism, critical animal studies and queer ecology, among others, they suggest that "[m] any subfields in the environmental humanities ... hold the conviction that the wounds of the natural world are also social wounds." "[T] he planetary ecological crisis," they continue, "is the material and historical consequence of an anthropocentric and dualistic worldview" (4).

These depictions of the environmental humanities echo the notion of a "crisis discipline" put forward by biologist Michael Soulé back in 1985. He was characterizing the field of conservation biology and saw it as a new mission-orientated endeavor with pressing timelines. As one of Soulés peers later put it, "[we] do not have the luxury of time to slowly and timidly reveal [our] . . scientific contributions to the world. We must act quickly if we are to influence species extinction rates, habitat loss, and the human condition" (Meffe 2001, 303). Of course, in the case of the environmental humanities, the contributions are not "scientific" in the conventional sense of that word-though they are considered and sophisticated. Variously using evidence, argument, critique, qualitative techniques and comparative methods, humanists seek to (1) reveal the different societal drivers of the planetary crisis and (2) identify alternative ways of thinking and acting that might serve to mitigate or avoid the crisis. Examples of each move are legion. Take the journal ISLE (Interdisciplinary Studies in Literature and Environment): it contains dozens of studies of how crisis and its aftermath are figured creatively in works of popular literature (like Margaret Atwood novels). Or consider plenary concepts like the Chthulucene (advanced by Donna Haraway), transgressive approaches like the "post-humanities," mature fields like environmental ethics, or the efforts of anthropologists and human geographers to decolonize thought by foregrounding indigenous worldviews (for a striking example see the paper authored by Bawaka Country et al. (2019)).

In these ways, many environmental humanists are exposing and expanding our grasp of what global change scientists have called, far too anemically, human dimensions. The nature of these dimensions is hidden in a generic, descriptive notion like The Great Acceleration. What has caused the planetary crisis, what human impacts is it having (and will it have), and how should people respond? Each part of 
this question requires an elucidation of meanings - both those held by the "real world" actors involved in the unfolding drama of global environmental change, and those constructed by analysts across the disciplines (including geoscientists). In respect of the latter point, environmental humanists adopt both a sympathetic and critical perspective on the science of Hansen, Mann and others. They accept crisis-claims in good faith while also widening the cognitive and normative vocabulary necessary to grasp just what sort of crisis we are facing (and deconstructing the "we" of humanity in the process). That is, they open "black box" concepts like "the human enterprise," which Paul Crutzen, Will Steffen and other geoscientists routinely use to gloss the complexities of society (Steffen et al. 2007; Steffen et al. 2011).

In sum, there's much to commend in the view that the environmental humanities is, at base, an interdisciplinary "crisis field." Where geoscientists are speaking of a planet in crisis, humanists are speaking for a world where the societal causes, impacts and responses to crisis need to be narrated and communicated widely. In this light, the challenges for the immediate future might seem to be two-fold: (1) how to coordinate research within the environmental humanities and between it and STEM disciplines; (2) how to make the environmental humanities more visible and impactful outside universities. I will come to these important challenges of organization and promotion momentarily (and many others are, of course, discussing and acting to address them too). But first I want to question something I've seemingly endorsed so far. There are, I think, real risks arising if too many environmental humanists self-identify as crisisanalysts and/or take the geoscientific claims of actual or imminent crisis at face value. A more measured approach is advisable.

\section{Qualifying the Crisis Frame: Between Is and Ought, Evidence and Argument, Fact, and Value}

Some social scientists and many humanities scholars have long insisted that all notions of crisis are socially constituted and can congeal into "social facts" that get employed strategically by some actors, even as others resist the designation (see, for instance, Jeffrey Alexander's book (2019)). It may, however, seem perverse to acknowledge that the so-called "global environmental crisis" is not an objective reality. It appears to contradict leading-edge geoscience, and even to be flagrantly irresponsible. It may thereby rob the environmental humanities of their raison d'etre - at least if the likes of Emmett and Nye are right that an unprecedented human impact on Earth animates this multidisciplinary field. 
Fortunately, however, we're not forced to choose between "social construction" and scientific realism as if it's an either/or issue. While it's important to acknowledge geoscientific evidence and model predictions, reports of anthropogenic Earth System change do not automatically entitle scientists (or anyone else) to talk of a crisis. Crisis is not simply a cognitive concept based on hard evidence; it's also normative, deriving a critical charge from (contestable) value judgements about what the evidence signifies morally, practically or aesthetically. In a classic article, philosopher Max Black (1964) showed that an "is" implies a definite "ought" only under quite restrictive conditions. Even the COVID-19 crisis is not nearly as much of a "tornado" situation as it appears. Yes, it poses a clear mortal threat to people. But how one responds to it in the longterm and even the short-term is, in fact, up for grabs: a panoply of choices exist and they need to be justified ones. For instance, in the future should governments ban wet markets, should they prevent illegal wildlife hunting or should they treat hunting as a symptom and tackle its root socio-economic causes? Likewise, global environmental change is, and will in future become, a "crisis" not on the basis of sheer biophysical impacts. A whole set of social practices and judgements relating to valued things (not all of which are basic necessities, like clean water) come into play. Crises are material and discursive; universal definitions scarcely ever apply.

In this light, environmental humanists can do two things (a few do them already). First, they can help geoscientists make explicit what they tend to leave implicit: namely, the reasons, irreducible to evidence or model predictions alone, to talk of a worldwide "crisis" in-the-making. These reasons cannot be solely or even strictly scientific. Happily, there is evidence that colleagues in STEM are increasingly alert to the extra-scientific components of their science (e.g. see Haikola et al.'s (2019) recent paper). Second, humanists can help non-scientists better understand how and why any putative crisis is not seen in the same way, or even as a crisis, by actors positioned differently in social and geographic terms. Neither stance prevents humanists making their own justified claims about why "crisis" is the correct word to describe our times-for instance, Eileen Crist (2019) does this in her new book Abundant Earth. But it creates some critical distance between the environmental humanities, geoscience and their potential audiences outside academia.

This distance is helpful. It could help bolster the authority of geoscience by reducing a long-run tendency to scientize value questions (an example of such scientization is Lenton et al.'s (2019) problematic attempt to mathematise "climate emergency" in a universal formula). It could also help improve wider literacy about the nature of crisis and its implications. To some degree this literacy exists, courtesy of writers like Clive Hamilton (2017) who strongly make the case for crisis-aversion. But 
beyond the well-worn environmentalist themes of a planet in peril, there are other narratives worth relaying about the "why, where, what and who?" of crisis. One of them is the way crisis-claims can be misused as rhetorical smokescreens or in sincere but problematic ways (e.g. to justify potentially high-risk UN-led future interventions, like solar radiation management). Another is the way crisis claims can produce panic or hopelessness, thereby rebounding on themselves. Rather than hitch its many wagons to crisis diagnosis and response, the environmental humanities could (and should) take a more measured "both/and" stance. This stance entails always explaining in what ways, and for what reasons, any "crisis" is (or is seen not to be) precisely that. De-objectifying crisis is not relativist but, instead, a mark of responsibility.

\section{How to Make the Environmental Humanities More Integrated and Visible?}

In closing, let me briefly explore the issues of integration (within and beyond the environmental humanities) and visibility outside the universities where most environmental humanists work. The two themes have loomed large in recent stocktakes of the environmental humanities by figures like Greg Garrard, Ursula Heise and Joni Adamson.

Hetan Shah (2020), chief executive of the British Academy, recently wrote this in Nature: "Without the humanities ... hard science and technology can do little to resolve complex societal challenges" (295). This is a correct, if now familiar, refrain. The problem is that many experts in the STEM world think "functional interdisciplinarity" - the term is Barry and Born's - is the only form that exists. They seem to hew to a monistic ontology, presuming that there's but one world-such that humanists (and social scientists) can fill knowledge-gaps to reveal a more complete picture of a single reality. This presumption may strike some economists or environmental planners as uncontentious. Yet most environmental humanists know that plural meanings underpin various acts of description, explanation, prediction, critique and normative reasoning. Such plurality is not symptomatic of confusion: it reflects legitimate disagreement and can be fecund. Working with STEM specialists cannot therefore (only) be about pretending there's one story to tell about "human dimensions" of environmental change. For instance, if we take seriously indigenous cosmologies, this may alter the kind of "science" that is relevant to identifying perceived problems and solutions of environment and society (for a fine example, see Wilcock, Brierley and Howitt (2013) on "ethno-geomorphology"). Likewise, the hermeneutics of the "environmental handprint" concept alter (in value-led ways) the scientific targets 
when compared to the familiar concept of an "environmental footprint" (see Guillaumme et al. (2020)).

A range of STEM-humanities interactions are possible and desirable, some in the vein of what Andrew Barry and Georgina Born (2013) have called "agonistic interdisciplinarity." True, within the environmental humanities there may be a certain "structure of feeling" that prevails - but no one should be aiming for a tightly-knit field that is "ready to wear" for our science and technology colleagues across campus. Nor, politically, should a broad "red-green" sensibility be perceived as the field's distinguishing normative feature-that might serve to make some STEM collaborations harder unless it is a very open sensibility. Conventional forms of interdisciplinary working might be very useful for addressing well-constrained ("tame") problems. But global environmental change is, to use a now hackneyed word, "wicked." Environmental humanists, working with others, can help to avoid analytical and normative grid-lock in the face of such wickedness. Pielke, in The Honest Broker (2007), talked of "abortion politics" situations, where complex, high-stakes problems engender partisan responses of "deaf and blind" communication among those affected. Interdisciplinary work of the right kind can help better communication flourish in "the age of consequences." It can support "pluriversal" thinking and action (cf. Escobar 2020). As Greg Garrard (2019) wisely notes, global environmental change "is a predicament we must face rather than a problem we can solve" (10).

Finally, what of the environmental humanities' public face? For years, angst has been expressed about why the value of the humanities is not more widely understood-especially in periods when universities are under financial pressure (e.g. Bate 2011). The angst has gone hand-in-hand with arguments for, and examples illustrative of, the positive role the humanities (can) play in society (e.g. Small 2013). In some cases, this role is depicted in terms of a new "consilience" with STEM (e.g. Slingerland 2008). The environmental humanities cannot afford to be slow and timid given the profundity of their subject matter. Visibility is crucial and could take many forms. But, of course, it's not easy to achieve and sustain over time, especially in the absence of "newsworthy" findings of the sort the IPCC routinely reports.

I have argued elsewhere that the environmental humanities would benefit from institutionalized global visibility which, in turn, could benefit governments and citizens worldwide (Castree, forthcoming). There has already been institutionalization-to a point (e.g. the Humanities for Environment observatories: https://hfeobservatories.org/). Suitably repurposed, global environmental assessments are one viable additional vehicle. For instance, the Intergovernmental Platform on Biodiversity 
and Ecosystem Services already contains clear openings for humanistic thinking. But more can be done here and elsewhere. Future assessments would no longer mostly assess scientific evidence about present day and prospective biophysical change. They would also assess a range of arguments, axiomatic values, policy proposals and technologies that are being proposed as possible ways of handling "wickedness." Assessments would be overtly political without being politically prescriptive. They would help to make "global public reason" more of a reality than it currently is. STEM insights and technologies could, I argue, be contextualized in a plethora of "valuesmeans-ends" packages (see Castree et al. 2014). Systematic assessment of these on cognitive and normative grounds would open-up thinking about whether (1) a metaphorical tornado is indeed coming our way, and (2) how we should seek to avert possible disaster or even less severe impacts. None of this would be easy to action, but it's arguably necessary (or, at the very least, desirable) as a next step for the environmental humanities.

\section{Conclusion}

If geoscientists speak for the Earth, who will speak for humanity? If geoscientists make descriptive, explanatory and predictive claims about the Earth System, who will speak morally, aesthetically or in policy terms for the non-human world? And how to speak of a world at once globally integrated yet intensely differentiated? In addressing these sorts of questions, I've made three points about representing people and planet in an age of consequences. The environmental humanities will need to be steered more purposefully if my suggested answers are to be actioned. The further question then becomes: how, precisely, to direct collective activity without impinging unduly on academic freedom?

\section{References}

Alexander, Jeffrey. 2019. What Makes a Social Crisis? Cambridge: Polity Press.

Bate, Jonathan. 2011. The Public Value of the Humanities. London: Bloomsbury.

Barry, Andrew, and Georgina Born. 2013. Interdisciplinarity: Reconfigurations of the Social and Natural Sciences. London: Routledge.

Black, Max. 1964. “The Gap between 'Is' and 'Should'." Philosophical Review 73 (2): 165-81.

Castree, Noel, William M. Adams, John Barry, Daniel Brockington, Bram Büscher, Esteve Corbera, David Demeritt, et al. 2014. "Changing the Intellectual Climate." Nature Climate Change 4 (9): 763-68.

- - - Forthcoming. "The Future of Global Environmental Assessments: A Case for Fundamental Change.” Anthropocene Review. 
Churchill, Winston. 2003. "The Locust Years." In Never Give In! Winston Churchill's Speeches, edited by Winston S. Churchill, 142-43. London: Pimlico.

Bawaka Country, Sandie Suchet-Pearson, Sarah Wright, Kate Lloyd, Matalena Tofa, Laklak Burrarrwanga, Ritjilili Ganambarr, Merrkiyawuy Ganambarr-Stubbs, Banbapuy Ganambarr, and Djawundil Maymuru. 2019. “'Bunbum Ga Dhä-yutagum’: To Make It Right Again, To Remake." Social and Cultural Geography. https://doi.org/10.1080/14649365.2019.1584825.

Crist, Eileen. 2019. Abundant Earth. Chicago: Chicago University Press.

Emmett, Robert S., and David E. Nye. 2017. The Environmental Humanities. Cambridge: MIT Press.

Escobar, Arturo. 2020. Pluriversal Politics: The Real and the Possible. Durham: Duke University Press.

Garrard, Greg. 2019. "Never Too Soon, Always Too Late: Reflections on Climate Temporality.” WIRES: Climate Change 1l (1): e605. https://doi.org/10.1002/wcc.605.

Guillaumme, Joseph H.A., Suvi Sojamo, Miina Porkka, Dieter Gerten, Mika Jalava, Leena Lankoski, Elina Lehikoinen, et al. 2020. "Giving Legs to Handprint Thinking: Foundations for Evaluating the Good We Do." Earth's Future 8 (6): e2019EF001422. https://doi.org/10.1029/2019EF001422.

Haikola, Simon, Anders Hansson, and Mathias Fridahl. 2019. "Mapmakers and Navigators of Political Terrain: Expert Assessments of Epistemological Uncertainty in Integrated Assessment Modelling of Bioenergy Carbon Capture and Storage." Futures 114 (December). https://doi.org/10.1016/j.futures.2019.102472.

Hamilton, Clive. 2017. Defiant Earth. Cambridge: Polity Press.

Lenton, Timothy M., Johan Rockström, Owen Gaffney, Stefan Rahmstorf, Katherine Richardson, Will Steffen, Hans Joachim Schellnhuber, et al. 2019. "Climate Tipping Points: Too Risky to Bet Against." Nature 575, no. 7784 (November): 592-95.

Mann, Michael E. 2014. "If You See Something, Say Something." New York Times, January 17. https://www.nytimes.com/2014/01/19/opinion/sunday/if-you-see-something-saysomething.html.

Meffe, Garry K. 2001. “Crisis in a Crisis Discipline.” Conservation Biology 15 (2): 303-4.

Nightingale, Andrea Joslyn, Siri Eriksen, Marcus Taylor, Timothy Forsyth, Mark Pelling, Andrew Newsham, Emily Boyd, et al. 2020. "Beyond Technical Fixes: Climate Solutions and the Great Derangement." Climate and Development 12 (4): 343-52.

Oppermann, Serpil, and Serenella Iovino, eds. 2017a. Environmental Humanities. New York: Rowman \& Littlefield.

Oppermann, Serpil, and Serenella Iovino. 2017b. "The Environmental Humanities and the Challenges of the Anthropocene." In Environmental Humanities, edited by Serpil Oppermann and Serenella Iovino, 1-21. New York: Rowman \& Littlefield.

Pielke, Roger A. 2007. The Honest Broker. Cambridge: Cambridge University Press.

Ripple, William J., Christopher Wolf, Thomas M. Newsome, Phoebe Bernard, and William R. Moomaw. 2020. "World Scientists' Warning of a Climate Emergency." BioScience 70, no. 1 (January): 8-12. https://doi.org/10.1093/biosci/biz088.

Shah, Hetan. 2020. "Global Problems Need Social Science." Nature 577 (January): 295.

Slingerland, Edward. 2008. What Science Offers the Humanities. Cambridge: Cambridge University Press.

Small, Helen. 2013. The Value of the Humanities. Oxford: Oxford University Press.

Soulé, Michael E. 1985. “What Is Conservation Biology?” BioScience 35 (11): 727-34. 
Steffen, Will, Paul J. Crutzen, and John R. McNeill. 2007. "The Anthropocene: Are Humans Overwhelming the Great Forces of Nature?" Ambio 36 (8): 614-21.

Steffen, Will, Asa Persson, Lisa Deutsch, Jan Zalasiewicz, Mark Williams, Katherine Richardson, Carole Crumley, et al. 2011. "The Anthropocene: From Global Change to Planetary Stewardship.” Ambio 40 (7): 739-61.

Steffen, Will, Katherine Richardson, Johan Rockström, Sarah E. Cornell, Ingo Fetzer, Elena M. Bennett, Reinette Biggs et al. 2015. "Planetary Boundaries: Guiding Human Development on a Changing Planet." Science 347 (6223). https://doi.org/10.1126/science.1259855.

Wilcock, Deidre, Gary Brierley, and Richard Howitt. 2013. "Ethnogeomorphology." Progress in Physical Geography 37 (5): 573-600. https://doi.org/10.1177/0309133313483164. 